DOI: http://doi.org/10.21698/simi.2018.ab21

\title{
USE OF ELECTROCOAGULATION AS A POLISHING STEP WITHIN TREATMENT OF FLUORIDE-RICH INDUSTRIAL EFFLUENTS
}

\author{
Monica Ihos, Mihaela Dragalina, Iuliana Iordache, Neidoni Dorian \\ National Research and Development Institute for Industrial Ecology ECOIND, Timisoara \\ Subsidiary, 115 Bujorilor, 300431, Timisoara, monica ihos@yahoo.com, ecoind.tm@gmail.com, \\ Romania
}

Keywords: electrocoagulation, fluoride, industrial effluents, removal

\section{Introduction}

Industrial effluents containing high concentration of fluoride are originated from many chemical processes, particularly those involved in the semiconductor, solar cell, plating, and metal manufacturing industries. Fluoride concentration from these industries can range from hundreds to thousands ppm. Therefore, effluents containing fluoride are to be treated in order to reduce their concentration to limit allowed by regulations in use before their discharge into sewerage systems or surface waters. This study aimed to remove the fluoride from a simulated high fluoride concentration industrial effluent by precipitation followed by electrocoagulation as polishing step.

\section{Materials and methods}

All reagents were of analytical grade and the solutions were prepared with distilled water. A simulated industrial effluent of $1000 \mathrm{mg} / \mathrm{L}$ fluoride was prepared. In the first step fluoride was removed by precipitation. $\mathrm{MgSO}_{4} \cdot 7 \mathrm{H}_{2} \mathrm{O}$ was added to the effluent in molar ratio $\mathrm{Mg}: \mathrm{F}$ of 1:2. The $\mathrm{pH}$ was adjusted to 9.6 with $\mathrm{NaOH}$ and the stirring was kept during 30 minutes. Low-porosity paper was used to separate the precipitate. The solution thus obtained was of $222 \mathrm{ppm}$ fluoride. In the second step, the fluoride removal was carried out by electrocoagulation from the solution resulted in first step. The working conditions were: sacrificial anode $\mathrm{Al} ; \mathrm{pH}$ of 5.2, 6.2 and 7.2, respectively; applied current densities of 100,200 and $300 \mathrm{~A} / \mathrm{m}^{2}$, respectively; electrolysis time 60 minutes; $0.01 \mathrm{M} \mathrm{NaCl}$ as supporting electrolyte. Samples were taken at every 15 minutes. The fluoride concentration was determined by using a Thermo Scientific Orion fluoride ion selective electrode.

\section{Results and conclusions}

At initial $\mathrm{pH}$ of 5.2, at any electrolysis time the increase of fluoride removal efficiency was recorded as the applied current density increased, but exceptions occurred at initial $\mathrm{pH}$ of 6.2 and electrolysis time of 45 and 60 minutes, respectively, when the fluoride removal efficiency was slightly higher at $200 \mathrm{~A} / \mathrm{m}^{2}$ versus $\quad 300 \mathrm{~A} / \mathrm{m}^{2}$. When the initial $\mathrm{pH}$ was 7.2 at electrolysis time of 15 and 45 minutes, respectively, the fluoride removal efficiency increased as the applied current density increased, while at 30 and 60 minutes, respectively, the maximum of fluoride removal efficiency was obtained at $300 \mathrm{~A} / \mathrm{m}^{2}$.

The linear dependence of fluoride removal efficiency on electrolysis time or current density and its exceptions can be explained by Faraday's Law according to the amount 


\section{INTERNATIONAL SYMPOSIUM "THE ENVIRONMENT AND THE INDUSTRY", SIMI 2018, BOOK OF ABSTRACTS}

of dissolved $\mathrm{Al}$ is directly proportional to the amount of electricity passing through the solution during electrocoagulation.

That is why the higher amount of electricity, the higher the amount of coagulant and the generated bubbles. Thus, by increasing the current density, the formation rate of $\mathrm{Al}^{3+}$ and $\mathrm{OH}^{-}$ions will increase. If the solution becomes excessively alkaline due to the formation of more $\mathrm{OH}^{-}$, the amount of $\mathrm{Al}(\mathrm{OH})_{3}$ decreases because it is well known that it is amphoteric and thus the amount of $\mathrm{F}^{-}$removed decreases.

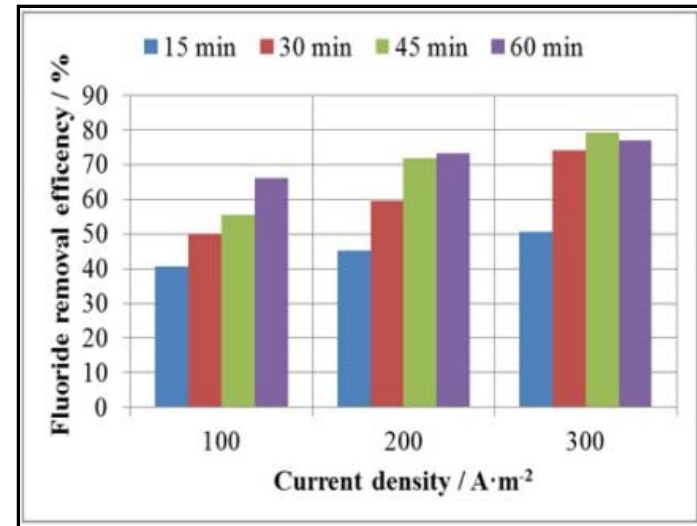

Figure 1. Fluoride removal efficiency by electrocoagularion at $\mathrm{pH} 5.2$

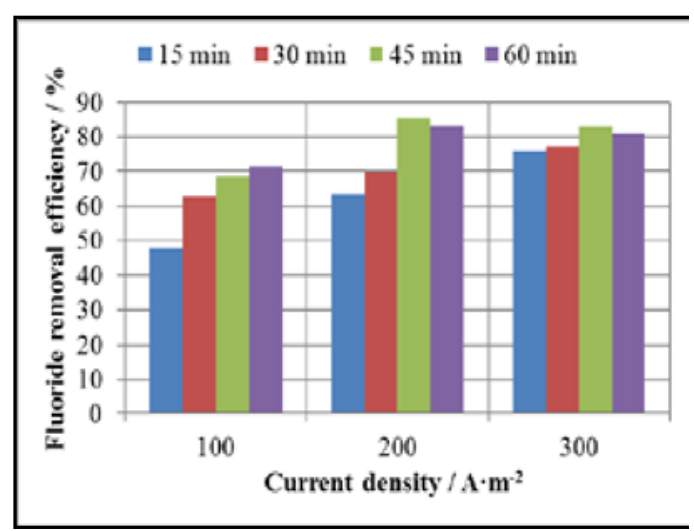

Figure 2. Fluoride removal efficiency by electrocoagularion at $\mathrm{pH} 6.2$

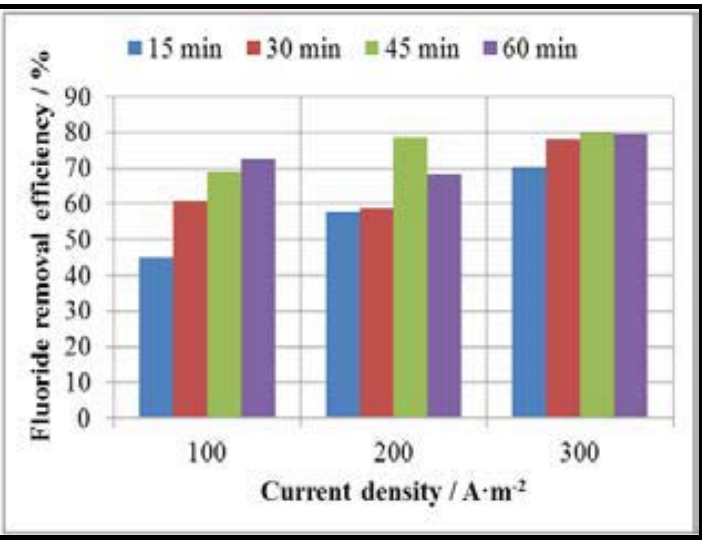

Figure 3. Fluoride removal efficiency by electrocoagularion at $\mathrm{pH} 7.2$
The use of electrocoagulation as a polishing step within treatment of fluoride-rich industrial effluents proved to be effective. The electrocoagulation was applied after the precipitation of fluoride with $\mathrm{MgSO}_{4} \cdot 7 \mathrm{H}_{2} \mathrm{O}$. The best result for fluoride removal efficiency by electrocoagulation was $85.39 \%$ (working conditions: $\mathrm{pH}$ of $6.2,200$ $\mathrm{A} / \mathrm{m}^{2}$ and 45 minutes of electrolysis) that leaded to an overall fluoride removal efficiency of $96.76 \%$.

\section{Acknowledgements}

This work was supported by a grant of the Romanian Nucleu Programme, Project PN 162503 07. 